\title{
PENGENDALIAN EMISI KARBON DAN PERUBAHAN STRUKTUR NAFKAH RUMAH TANGGA PETANI: ANALISIS SOSIOLOGI NAFKAH
}

\author{
Arya Hadi Dharmawan*), Lilik Budi Prasetyo, Fredian Tonny Nasdian, \\ Faris Rahmadian, Fatimah Azzahra, Deasy Fitria, Indri Febriani \\ Pusat Studi Pembangunan Pertanian dan Pedesaan (PSP3) - LPPM, IPB Bogor \\ *)E-mail: aryahadidharmawan@gmail.com
}

\begin{abstract}
The development of carbon-based society is one of the contemporary issues that offers a form of environmental and human collaboration respirokal also functional in controlling the risks of climate change.However, its not easy to introduce the issue of carbon to the livelihood systems of rural communities. In it, found a variety of problems, from technical aspects to non-technical. This study was constructed to answer these issues in the wider framework to mitigate climate change by carbon credits in two different locations, namely in the Daerah Istimewa Yogyakarta (DIY) and Jambi. For the case of DIY, carbon trading scheme, which is based on the Voluntary Carbon Market (VCM) still pose a constraint on the aspect of "legalization" and "market". Besides the licensing process and the disharmony between institutions vertically led to increasingly complex problems. As for the case in Jambi Province, the forest is seriously threatened by forest fires and property issues (tragedy of the common), the lack of public knowledge about the functioning of Forest Park (TAHURA) causes some people consider the forest and the free open access to be entered.In another side, the TAHURA is one potential area that has a large enough carbon stocks as the area of climate change mitigation. This research is ultimately going to map out the problems and calculate the economic contribution obtained by the public, as well as changes in the structure of living in two locations with two carbon initiatives of community-based schemes are different.
\end{abstract}

Keywords: mitigation of climate change, carbon emissions, the development of community-based carbon, a living structure, sociology of rural living

\begin{abstract}
ABSTRAK
Pengembangan karbon berbasis masyarakat merupakan salah satu isu kontemporeryang menawarkan bentuk kolaborasi manusia dan lingkungan yang respirokal juga fungsional dalam upaya pengendalian resiko perubahan iklim.Namun, tidak mudah memperkenalkan isu karbon ke dalam sistem penghidupan masyarakat pedesaan. Di dalamnya,ditemukanberbagai permasalahan, dari aspek teknis hingga non-teknis. Penelitian ini dikonstruksikan untuk menjawabberbagai persoalan tersebut dalam kerangka besar mitigasi perubahan iklim via kredit karbon di dua lokasi yang berbeda, yakni di Provinsi Daerah Istimewa Yogyakarta (DIY) dan Provinsi Jambi. Untuk kasus di DIY, skema perdagangan karbon yang berlandaskan pada Voluntary Carbon Market (VCM) masih menimbulkan kendala pada aspek "legalisasi" dan "pasar". Selain itu proses perizinan dan disharmoni antar lembaga secara vertikal menyebabkan persoalan semakin kompleks. Sedangkan untuk kasus di Provinsi Jambi, hutan pada saat ini sangat terancam dengan kebakaran hutansertapersoalan properti (tragedy of the common), minimnya pengetahuan masyarakat tentang fungsi Taman Hutan Raya (TAHURA) menyebabkan sebagian masyarakat menganggap kawasan hutan tersebut open access dan bebas untuk dimasuki.Di sisi lain, kawasan TAHURA merupakan salah satu kawasan potensial yang memiliki cadangan karbon yang cukup besar sebagai kawasan mitigasi perubahan iklim. Penelitian ini pada akhirnya hendak memetakan permasalahan dan mengkalkulasikan kontribusi ekonomi yang diperoleh oleh masyarakat, serta perubahan struktur nafkah di dua lokasi dengan dua skema inisiatif karbon berbasis masyarakat yang berbeda.
\end{abstract}

Kata kunci: mitigasi perubahan iklim, emisi karbon, pengembangan karbon berbasis masyarakat, struktur nafkah, sosiologi nafkah pedesaa

\section{PENDAHULUAN}

\section{Latar Belakang}

Isu perubahan iklim dan penurunan emisi karbon $(\mathrm{CO} 2)$ telah memasuki bidang ilmu-ilmu sosial melalui kajian sistem nafkah pedesaan atau sosiologi nafkah pedesaan sejak beberapa tahun terakhir (Dharmawan 2007; Groom dan Palmer 2012). Secara teoretik, semakin banyak karbon yang diakumulasikan pada sistem pertanian rumahtangga petani seperti agro-forestry mereka (Agrawal et al 2014), maka semakin besar potensi pembayaran karbon (annual carbon payments), sebagai hasil partisipasi rumahtangga petani dalam REDD+ (Reducing Emission from Forest Degradation and Deforestation), masuk ke dalam sistem nafkah mereka (Boyd et al 2006; ItuarteLima et al. 2014; Irawan et al 2013; Newton et al. 2015). Semakin besar partisipasi rumahtangga dalam agro-forestry yang memungkinkan tambahan akumulasi karbon pada satuan kawasan tertentu, semakin besar potensi pendapatan rumahtangga dari pembayaran karbon setiap tahun ke dalam sistem nafkah mereka (Caplow, et.al., 2011; Willemen, et.al., 2013). Bahkan, optimisme tentang mekanisme REDD+ sampai pada keyakinan untuk mengaitkannya pada pemberantasan kemiskinan di pedesaan (Fisher, et al, 2014).

Telah banyak inisiatif yang dilakukan baik oleh pemerintah, organisasi non pemerintah, maupun komunitas untuk menangkap pembiayaan dalam skema REDD+ (Luttrell et al 2014; Skidmore et al 2014). Namun dari berbagai kajian dan studi kasus implementasi skema REDD+ di Indonesia masih banyak mengalami kendala. Bahkan pilot project yang dilaksanakan pertama kali di Kalimantan Tengah sejak tahun 2008 sampai saat ini belum memperlihatkan hasil (mengalami kegagalan). Studi kasus San Giorgio Group (Rosenberg dan Wilkinson, 2013) di Kalimantan Tengah menyatakan bahwa salah satu hambatan utama untuk investasi dalam kegiatan 
REDD + di Indonesia adalah kurangnya kejelasan mengenai aturan tentang tata ruang dimana ketentuan yang ada tidak memadai dan kontradiktif serta tumpang tindih dalam pemberian hak pengelolaan lahan dan hutan. Belum lagi tekait dengan kegagalan dalam mempertahankan hubungan kerjasama dalam komunitas, dimana komunitas seringkali sebatas menjadi obyek yang mau tidak mau mendapatkan dampak negatif maupun positif akan adanya program baik secara langsung maupun tidak langsung.

Hal ini terutama dikaitkan dengan resiko hilangnya sumber nafkah bagi masyarakat setempat yang sebelumnya tergantung dari hutan jika harus menghilangkan atau mengganti sumber nafkah dari non hutan. Hambatan terakhir terkait dengan ketidakpastian siapa yang akan mendapatkan keuntungan dari skema REDD+. Hal ini juga sesuai dengan hasil studi CIFOR (Sunderlin, 2010) yang menyatakan salah satu kendala dalam skema REDD+ adalah ketidakjelasan dalam menentukan siapa yang dapat menguasai dan menggunakan lahan hutan dan sumber daya. Termasuk untuk berapa lama dan pada kondisi apa skema pembayaran diberikan. Hal ini sulit dilakukan di Indonesia karena kurang jelasnya status pemilikan lahan dan hutan yang secara umum hanya terbagi menjadi dua, yaitu (a) kepemilikan adat (ditentukan di tingkat lokal/ "masyarakat memiliki hutan") dan (b) kepemilikan negara (ditentukan oleh pemerintah).

Di lain pihak, banyak inisiatif lokal yang dilakukan baik oleh LSM tingkat lokal maupun komunitas untuk menangkap adanya skema REDD+.Sejalan dengan program sistem verifikasi legalitas kayu, kelompok petani hutan rakyat yang pada umumnya didampingi oleh LSM lokal mengarahkan sistem pengelolaan hutan untuk mendapatkan manfaat dari adanya skema REDD+ (Vatn dan Vedeld 2012).Namun sampai sejauh ini belum ada kepastian mengenai pembeli karbon baik dari international maupun dari domestik (Skutsch et al 2011). Hal ini terjadi karena kesiapan kelembagan pengelolaan REDD+ secara nasional yang mengatur skema jual beli karbon sampai sejauh ini juga masih belum ada kejelasan (Lyster 2011). Yang ada, masyarakat lokal yang sudah memiliki kesadaran untuk menanam pohon masih belum mendapatkan manfaat dari berbagai skema REDD+ yang selalu menjadi harapan untuk meningkatkan kesejahteraan hidupnya.

Pada saat ini permasalahan lingkungan tidak hanya dapat dipandang dari satu sisi, begitupun dengan upaya penyelesaiannya (Collier et al 2011). Permasalahan lingkungan di sektor kehutanan khususnya, seperti illegal logging, kebakaran hutan, dsb. tidak hanya dapat diselesaikan apabila pendekatan yang dilakukan terlalu top-down. Penyelesaian permasalahan tersebut harus mampu melibatkan lapisan yang bersentuhan langsung dengan objek agraria tersebut, atau dalam hal ini masyarakat lokal Seiring perkembangannya konsep REDD+ dikembangkan dengan berbagai metode yang inklusif dan dalam kerangka upaya mensejahterakan masyarakat lokal (Suiseeya et al. 2013). Payment for environmental services diturunkan hingga menyentuh masyarakat yang berada bersebelahan langsung dengan hutan, konsep ini menghasilkan masyarakat yang prolingkungan serta pro-ekonomi (Strassburg et al. 2009).

Dimana dalam prosesnya hingga saat ini karbon dijadikan sebagai komoditas perdagangan yang dapat menjanjikan. Perdagangan karbon dapat dikonstruksikan menjadi beberapa pola, seperti business to government, atau bahkan business to community. Konsep business to community pada akhirnya dianggap sebagai solusi yang dapat menjadi solusi dalam penyelesaian permasalahan lingkungan namun di satu sisi mengembangkan masyarakat dengan prinsip ekonomi dan ekologi untuk menciptakan sebuah lingkungan yang berkelanjutan.Oleh karena itu, kajian ini dilakukan untuk melihat bagaimana struktur nafkah masyarakat di Desa Ngeposari, Provinsi Daerah Istimewa Yogyakarta dan di Desa Sunga Aur, Provinsi Jambi.

\section{Rumusan Masalah}

Pada era ini, degradasi sumber daya alam (sektor kehutanan khususnya) tidak luput dari berbagai aktivitas manusia itu sendiri. Kegiatan manusia yang semakin memperparah terjadinya pemanasan global diantaranya adalah pembakaran lahan terutama di lahan gambut dan hutan, termasuk masih adanya aktivitas illegal logging yang jelas merusak ekosistem hutan serta hilirnya.

Kerakusan manusia akan lahan dengan mealukan pembuakaan hutan untuk perkebunan, pertambangan dan pemukiman semakin menmbah cepat laju deforestasi dan degradasi hutan yang tidak hanya mengancam sumber daya alam secara ekologis namun juga mengancam sistem penghidupan masyarakat terutama yang tinggal di sekitar hutan. Program REDD+ mendorong agar hutan tetap terjaga dan semakin luas sebagai penyerap karbon namun secara ekonomi tetap memberikan keuntungan khususnya bagi masyarakat lokal.

Oleh karena itu skema pembayaran karbon kemudian menjadi komitmen internasional meskipun sampai sekarang secara nyata wujudnya belum terlihat. Meskipun demikian, inisiatifinisiatif di tingkat lokal sudah banyak dilakukan baik oleh masyarakat, NGO, pemerintah daerah maupun pemerintah pusat.Namun dari kesemua inisiatif yang telah dilakukan sampai sejauh ini belum ada yang dikatakan "berhasil" karena belum ada paymentsecara nyataterhadap environmental services yang dilakukan. Oleh karena itu sebelumnya harus dipahami dan diproyeksikan bagaimana dinamika sektor dan kontribusi karbon dapat berpotensi terhadap stuktur nafkah rumah tangga. Hal ini menjadi penting sebagai identifikasi awal sebelum melompat ke dalam kerangka perdagangan karbon yang lebih luas.Oleh karena itu, berdasarkan uraian tersebut, maka penelitian ini akan membahas dua rumusan masalah sebagai berikut:

1. Sejauh mana potensi kontribusi karbon yang dapat diterima oleh masyarakat di Desa Ngeposari, Provinsi Daerah Istimewa Yogyakarta dan di Desa Sunga Aur, Provinsi Jambi?

2. Bagaimana dinamika kelembagaan dan kesiapan masyarakat di Desa Ngeposari, Provinsi Daerah Istimewa Yogyakarta dan di Desa Sunga Aur, Provinsi Jambi dalam menghadapi isu karbon berbasis masyarakat?

\section{Tujuan Penelitian}

Berdasarkan rumusan masalah penelitian, maka penelitian ini secara khusus bertujuan untuk:

1. Mengetahui sejauh mana potensi kontribusi karbon yang dapat diterima oleh masyarakat di Desa Ngeposari, Provinsi Daerah Istimewa Yogyakarta dan di Desa Sunga Aur, Provinsi Jambi.

2. Mengetahui dinamika kelembagaan dan kesiapan masyarakat di Desa Ngeposari, Provinsi Daerah Istimewa Yogyakarta dan di Desa Sunga Aur, Provinsi Jambi dalam menghadapi isu karbon berbasis masyarakat 


\section{TINJAUAN PUSTAKA}

\section{a. Struktur Nafkah Rumah Tangga}

Sistem nafkah atau sering dikenal dengan istilah mata pencaharian oleh Ellis (1988), didefinisikan sebagai aktivitas, modal, dan akses bahwa ikut serta/berhubungan dengan menentukan pendapatan hidup oleh seseorang atau rumahtangga. Sehingga menurutnya, diversifikasi mata pencaharian di pedesaan didenfinisikasi sebagai sebuah proses yang dibentuk rumahtangga. Dalam konteks sistem mata pencaharian hidup, dalam satu sistem kebudayaan keragaman mata pencaharian dapat terjadi dan berbeda untuk satu rumahtangga individu dengan yang lainnya. Sebagai sebuah sistem, perbedaan secara umum dalam sistem ini dapat dilihat dari basis pengelolaan sumberdaya alam. Menurut Koentjaraningrat (1990), dalam sistem mata pencaharian yang masih bersifat tradisional dapat dibedakan menjadi lima, yaitu (1) berburu dan meramu; (2) beternak; (3) bercocok tanam; (4) menangkap ikan; dan bercocok tanam menetap dengan irigasi. Perbedaan sistem mata pencaharian dalam masyarakat juga dipengaruhi oleh kondisi lingkungan fisik yang ada. Dan berdasarkan hal tersebut sistem mata pencaharian pada masyarakat yang berbasis tanah (sawah dan hutan) akan berbeda dengan sistem mata pencaharian masyarakat yang berbasis laut (nelayan). Dari perbedaan sistem mata pencaharian yang ada dalam masyarakat dimungkinkan terjadi perbedaan dalam struktur sosial yang ada di dalamnya dan bagaimana dinamika yang terjadi di dalamnya.

Dalam memperoleh pendapatan sebuah rumahtangga perlu menentukan strategi nafkah apa yang dapat dilakukan. Basis nafkah rumahtangga petani dari sisi ekonomi pertanian maupun ekonomi non-pertanian dapat dikaitkan dengan penelitian yang dilakukan oleh Diniz et al. (2013) mengenai strategi nafkah dalam program pengentasan kemiskinan di Amazon, Brazil. Hasil penelitian tersebut menunjukkan bahwa terdapat dua strategi nafkah yang dilakukan oleh masyarakat di Amazon berupa strategi on-farm yaitu budidaya dan berternak, maupun strategi off-farm yaitu usaha kecil, perdagangan pedesaan, dan pasar tenaga kerja. Pada penerapan strategi nafkah tersebut diidentifikasi bahwa masyarakat di wilayah Amazon tersebut menggunakan modal manusia (asal dan latar belakang), modal finansial (produksi susu dan kawanan ukuran), dan proses antara (akses pasar susu). Analisis secara kualitatif menunjukkan bahwa kombinasi faktor-faktor lain seperti modal alam (luas peternakan), modal fisik (jarak ke pasar susu), dan beberapa proses Mediasi (akses tanah, skema kredit, bantuan teknologi dan kapasitas organisasi) juga penting. Meskipun strategi nafkah timbul di tingkat individu, setiap akhir dari kegiatan ini didefinisikan pada tingkat rumahtangga. Definisi strategi nafkah adalah segala kegiatan atau keputusan yang diambil anggota rumahtangga untuk bertahan hidup (survival) dan atau membuat hidup lebih baik. Tujuan dari bertahan hidup, berarti membangun beberapa strategi untuk keamanan dan keseimbangan mata pencaharian rumahtangga (Dhamawan 2001).

\section{b. Karbon: Keseimbangan Ekonomi dan Ekosistem}

Indonesia merupakan salah satu negara yang menghasilkan gas rumah kaca yang cukup tinggi. Koordinator Komunikasi, Informasi dan Pendidikan Dewan Nasional Perubahan Iklim (DNPI) menyebutkan, bahwa kontribusi alih hutan terhadap emisi gas rumah kaca pada tahun 2013 saja yaitu 48 persen, kemudian diikuti energi (20 persen), pembakaran gambut (13 persen), sampah (11 persen), agrikultur (5 persen), dan industrial (3 persen). DNPI juga telah menetapkan rencana aksi pengurangan emisi gas rumah kaca secara bertahap hingga 2020. Menurut prediksi institusinya, emisi di Indonesia akan meningkat menjadi 2,95 Giga ton $\mathrm{CO} 2 \mathrm{e}$ pada 2020 mendatang. DNPI berupaya mengurangi 0,767 Giga ton CO2e atau 26 persen dari estimasi total emisi 2020. Selanjutnya, akan mengurangi emisi 0,422 Giga ton $\mathrm{CO} 2 \mathrm{e}$ atau 15 persen total emisi (Juniarto, Ngazis 2013).

Data dari DNPI telah menunjukkan bagaimana alih fungsi hutan (LULUCF atau Land use, land use change and forestry) berkontribusi sangat besar terhadap emisi karbon. Permasalahan emisi karbon tersebut pada akhirnya menyentuh pada tataran global. Inisiatif REDD+ (Reducing Emissions from Deforestation and Forest Degradation, Plus) dianggap menjadi cara jitu untuk pengurangan konversi lahan hutan dan pada saat yang bersamaan mendatangkan untung bagi negara-negara yang terlibat. Indonesia sendiri kini masih mengembangkan konsep implementasi REDD+. Pengembangan itu masih dalam proses dan masih ada beberapa masalah yang perlu diatasi sebelum keuntungan REDD + dapat diraih. Persoalan tersebut tidak hanya pada aspek konseptual, namun hingga teknis implementasi REDD+ itu sendiri, seperti teknologi penghitungan karbon yang tepat untuk diterapkan di Indonesia, skema pembayaran insentif, hingga akuntablilitas dan pendanaan proyek REDD (Agung 2010).

Bagi sebagian besar stakeholders, skema mitigasi iklim baik dengan skema perdagangan karbon (government to government atau business to community) merupakan salah satu upaya yang mampu menjadikan harmoni antara kepentingan ekosistem dan juga ekonomi (masyarakat lokal khususnya). Namun seperti disebutkan oleh Sayer dkk (2012), dalam segala program "pembangunan" atau "perbaikan" yang melibatkan alam dan masyarakat, sebaiknya aspek "masyarakat" harus juga diperhatikan secara lebih fokus karena kerap kali mereka tersingkirkan. Dan ketika masyarakat tersingkirkan, maka "pemulihan" ekosistem pun tidak akan dapat terlaksana sepenuhnya.

\section{METODE PENELITIAN}

Penelitian ini akan dilaksanakan di dua lokasi yang mewakili dua sistem tenurial dalam pengembangan karbon inisiatif berbasis masyarakat yang berbeda. Lokasi yang dipilih adalah: 1. Desa Ngeposari, Kecamatan Semanu, Kabupaten Gunungkidul, Provinsi Daerah Istimewa Yogyakarta yang mewakili inisiatif karbon pada hutan kemasyarakatan (HKm).

2. Desa Sungai Aur, Kecamatan Kumpeh. Kabupaten Muaro Jambi, Provinsi Jambi. Pengembangan komunitas karbon di lokasi ini dalam bentuk kemitraan antara masyarakat dan taman hutan 'raya (TAHURA).

Penelitian ini menggunakan pendekatan kualitatif dengan didukung pendekatan kuantitatif. Oleh karena itu metode yang digunakan untuk mendapatkan data dan informasi lebih banyak dilakukan dengan wawancara mendalam dan diskusi kelompok terfokus. Sementara itu, metode survey dilakukan terutaman untuk melihat keragaan sosial ekonomi komunitas. Secara lebih rinci metode pengumpulan data yang digunakan dalam penelitian ini sebagai:

1. In depth interview yaitu komunikasi secara lisan yang terstruktur untuk menggali informasi tentang identifikasipola-pola pengembangan karbon berbasis masyarakat yang sudah dilakukan pada dua tipe land tenure system. Dalam hal ini termasuk informasi mengenai kendala dan peluang kemitraan yang dapat 
dilakukan. Metode ini dilengkapi dengan panduan pertanyaan yang ditujukan kepada komunitas maupun pihak swasta yang dapat menjadi alternatif konsumin dalam kerangka REDD+.

2. Focus Group Discussion (FGD), merupakan kegiatan diskusi dengan para stakeholder atau tokoh masyarakat dengan berbagai tema penelitian, seperti hambatan dan tantangan dalam pengembangan karbon berbasis masyarakat sehingga dapat menjadi pembelajaran bagi kegiatan yang serupa dan peluang membangun kelembagaan dalam pengelolaan hutan dalam kerangka REDD+. Selain itu, melalui metode ini juga menjadi salah satu sarana untuk mengawali pertemuan antara masyarakat dengan pihak swasta untuk mendapatkan gambaran mengenai hambatan dan tantangan untuk menjalin kemitraan dalam kerangka REDD+.

3. Survei, yaitu pengamatan langsung obyek penelitian dengan tujuan untuk mendapatkan gambaran tentang kondisi sosial ekonomi, seperti tingkat ketergantungan masyarakat terhadap hutan/kayu sebagai sumber penghidupan, keberterimaan masyarakat terhadap inisiatif karbon yang dikembangkan, keragaman biodiversity yang ada di kawasan hutan yang dikembangkan masyarakat dan lain sebagainya yang berguna bagi pengembangan karbon berbasis masyarakat dan pola kemitraan dalam kerangka REDD+. Termasuk dalam harapan masyarakat terhadap peluang peningkatan kesejahteraan dengan adanya skema pembayaran karbon sebagai insentif. Instrumen yang digunakan untuk metode ini dengan menggunakan kuesioner sebagai panduan wawancara terstruktur.

Terkait dengan pengambilan sampel survei dilakukan dengan metode non probabilitas secara purposive sampling. Populasi sampel adalah masyarakat di Desa Ngeposari, Provinsi Daerah Yogyakarta dan masyarakat di Desa Sungai Aur, Provinsi Jambi. Populasi sasaran atau sampel yang akan dijadikan responden (atau unit analisisnya) adalah rumahtangga masyarakat yang terlibat maupun tidak dalam pengembangan karbon berbasis masyarakat. Hal ini ditujukan untuk melihat keragaman masyarakat dari aspek sosial-ekonominya. Sedangkan jumlah responden untuk masing-masing lokasi atau desa fokus penelitian adalah sebanyak 70 orang.

\section{Gambaran Lokasi Penelitian}

\section{Desa Ngeposari, Daerah Istimewa Yogyakarta}

Kabupaten Gunungkidul terletak antara 7o 46'- 8o 09' Lintang Selatan dan 110o 21' - 110o 50' Bujur Timur, yang berbatasan dengan Kabupaten Klaten, Kabupaten Sukoharjo, Jawa Tengah di sebelah utara. Kabupaten Wonogiri, Jawa Tengah di sebelah timur. Samudra Indonesia di sebelah selatan dan Kabupaten Bantul, Kabupaten Sleman, DI Yogyakarta di sebelah barat. Luas wilayah Kabupaten Gunungkidul tercatat 1.485,36 km2 yang meliputi 18 kecamatan dan 144 desa/kelurahan. Kecamatan Semanu merupakan salah satu kecamatan yang terleta di kawasan Gunung Kidul yang terluas, dengan luas sekitar 108,39 km2 atausekitar 7,30 persen luas Kabupaten Gunungkidul. Kondisi cuaca di wilayah kecamatan semanu adalah suhu rata-rata berkisar antara 29-31oC jumlah hari hujan dalam 1 tahun 103 hari dengan curah hujan $1.603 \mathrm{~mm} /$ th, sehingga termasuk dalam tipe iklim $\mathrm{C}$ menurut Schmidth Ferguson. Kondisi Geografi berada dalam dataran sampai berbukit-bukit, jenis tanah mediteran dan sedikit tanah aluvial,dan grumusol. Presentase batuan berupa batu kapur $50 \%$ menutupi sebagian permukaan tanahnya. Kondisi tersebut sempat menjadikan kawasan Gunung Kidul sebagai salah satu kawasan yang paling "kritis" di Indonesia, namun pada saat ini terdapat kawasan hutan yang dibangun oleh masyarakat dengan skema Hutan Kemasyarakatan (HKm).

Kawasan hutan negara mempunyai luas $13.000 \mathrm{Ha}$, telah dikelola oleh masyarakat dalam skema HKm seluas 1.087,65 ha. Dikelola 35 kelompok IUPHKm, tersebar 15 desa pada 4 kecamatan diwilayah Gunungkidul. Salah satu kelompok adalah Sedyo Makmur yang beralamat di Jragum, Neposari, Semanu Gunungkidul. Jumlah pengelola hutan yang tergabung dalam kelompok ini adalah $254 \mathrm{KK}$. Membentuk sub kelompok meliputi 7 sub yaitu sub 1-3 Jragum, sub 4-5 Wediutah, sub 6. Gemulung. Hkm bertujuan untuk meningkatkan fungsi kawasan hutan negara yang pemanfaatan utamanya ditujukan untuk memberdayakan masyarakat setempat. Sistem pengelolaannya melibatkan 3 komponen yaitu lahan hutan, teknologi pengelolaan, dan masyarakat sekitar. Sehingga sistem ini memberikan jaminan keberhasilan yang cukup besar, dengan adanya pelibatan masyarakat.

HKm pada dasarnya berada di kawasan hutan negara yang dikelola oleh masyarakat melalui skema yang 'dikelola sepenuhnya oleh rakyat', status ijin dari Bupati Gunungkidul no $214 / \mathrm{KPTS} / 2007$ tanggal 12 Des 2007 , berjangka waktu 35 tahun. Berada di petak 162, 163 RPH Semanu BDH Karangmojo, Kecamatan Semanu, Kabupaten Gunungkidul. Luas areal 115 Ha.Pada tahun 2008 setelah memperoleh IUPHKm tahun 2007 dilakukan pemetaan andil/garapan dan batas-batas luar dari kawasan yang dikelola masyarakat.

Kondisi tanah berbatu merata di HKM luas 115 ha dengan jenis tanah lempung/merah .topografi berbukit bukit dengan kelas lereng $40-60^{\circ}$. Ketinggian tanah $186 \mathrm{mdpl}$. Jenis penutupan lahan berupa tanaman jati dan perdu . Pola pengelolaan yang dilakukan petani KTH Sedyo Makmur pada umumnya merupakan pola agroforestry atau sering dikenal dengan pola tanam campur sari yaitu menanam berbagai jenis tanaman dalam satu lahan.

Jenis tanaman didominasi oleh tanaman kehutanan seperti jati dan kesambi. Tanaman jati dan kesambi yang ada cukup rapat dengan jarak tanam bervariasi dari $3 \times 2 \mathrm{~m}, 3 \times 3 \mathrm{~m}$ dan $4 \times 6$ m. Hal ini dikarenakan untuk beberapa areal HKm merupakan lahan HKm lama (tahun 1995/1996). Untuk jenis kesambi, walaupun tegakan yang ada merupakan tegakan lama namun lahan di bawahnya masih dapat ditanami dengan tanaman pertanian karena kebanyakan daunnya sudah habis dipangkas dan digunakan sebagai alternatif pakan ternak pada musim kemarau. Pada lahan-lahan yang masih bisa untuk pertanian sebagian ditanami pertanian seperti padi, jagung, kacang dan ketela. Kondisi tanah yang kurus (kurang subur) umumnya hanya ditanami jagung dan ketela pohon karena hanya jenis tanaman ini yang cocok.

Jumlah penduduk Ngeposari 9.477 jiwa terdiri dari lakilaki 4.656 jiwa dan penduduk perempuan 4.821 jiwa dalam 2.216 Kepala Keluarga. Mayoritas tingkat pendidikan penduduk tamatan SD. Banyak penduduk usia produktif yang merantau ke luar desa. Masyarakat Ngeposari mayoritas bermata pencaharian dari pertanian dan peternakan. Pengairan berasal dari tadah hujan sehingga dalam satu tahun hanya bisa bercocok tanam padi dan palawija dua kali. Sebagai penopang, masyarakat memelihara ternak khususnya sapi dan kambing. Hampir semua warga memiliki sapi minimal satu dan kambing minimal dua. Bahkan ada yang secara khusus sebagai penggemuk sapi. 


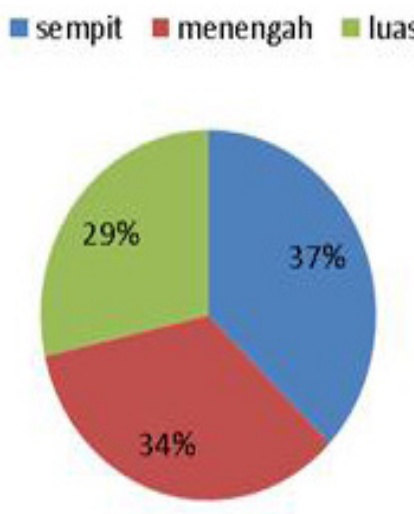

Gambar 1. Presentase Responden menurut Luas Lahan HKM di Desa Ngeposari, Kecamatan Semanu, Kabupaten Gunung Kidul, DIY Tahun 2015

\section{Desa Sungai Aur, Provinsi Jambi}

Secara geografis Desa Sungai Aur teletak di bagian Timur Kabupatan Muaro Jambi dan berada pada posisi $1^{\circ} 15^{\text {, }}$ Lintang Selatan sampai dengan 20 20, Lintang Selatan dan di antara 1020 30, Bujur Timur Sampai dengan 1040 Bujur Timur. Dengan batas wilayah sebagai berikut, sebelah Timur dengan Provinsi Sumatera Selatan, Sebelah Utara dengan Kec. Berbak, Kab Tanjung Jabung Timur, Sebelah Selatan dengan Desa Jebus, Kec Kumpeh dan Sebelah Barat dengan Kec. Dendang Kab. Tanjung Jabung Timur.

Klaim wilayah Desa Sungai Aur sendiri adalah 42,969 ha, dengan luas wilayah administrasi dan pemukiman $\pm 3,000$ ha serta sisanya atau sekitar $\pm 36,969$ ha masuk ke dalam kawasan Taman Hutan Raya (TAHURA) serta Taman Nasional Berbak (TN Berbak). Luas Wilayah Desa Sungai Aur yang dimanfaatkan dan teridentifikasi adalah \pm 823 ha, yang terdiri dari Tanah Sawah/ladang seluas $\pm 603,00$ ha, tanah pekarangan seluas $\pm 200,00$ ha. tanah tegalan seluas \pm 20 ha. Dengan luas lahan tersebut, jumlah penduduk desa Sungai Aur adalah 1.794 Jiwa atau dengan jumlah Kepala Keluarga sebanyak 516 KK yang tinggal dalam Tiga Dusun yang berbeda.

Masing-masing dusun pada Desa Sungai Aur ternyata memiliki karakteristik masing-masing yang khas. Pada Dusun 1, masyarakat cenderung lebih berkebun dan berwirausaha (termasuk di dalamnya mereka yang memiliki tanah yang juga menjadi bagian kemitraan / deviden dengan perusahaan perkebunan kelapa sawit). Sedangkan pada Dusun 2, masyarakatnya kurang lebih sama dengan masyarakat Dusun 1 namun beberapa diantaranya mulai bertani (kedelai dan padi ladang). Yang paling berbeda diantara kedua dusun tersebut adalah Dusun 3, masyarakat Dusun 3 pada dasarnya merupakan masyarakat transmigrasi yang sebagain besar berasal dari Jawa Timur dan Jawa Tengah. Kondisi tersebut pada akhirnya membawa warna yang berbeda dalam sistem / pola nafkah sebagian besar masyarakat Dusun 3. Hal ini ditandai dengan sebagian besar masyarakatnya bertani padi ladang (bahkan dapat dikatakan $85 \%$ basis pertanian Desa Sungai Aur berada pada Dusun 3). Bahkan dari aspek kelembagaan, gabungan kelompok tani Desa Sungai Aur yang berbasis di Dusun 3 sempat mendapat penghargaan dari pihak pemerintah provinsi karena hasil produksi pertanian yang tergolong sangat baik.

Menurut data dalam Profil Desa Sungai Aur, pada tahun 2014

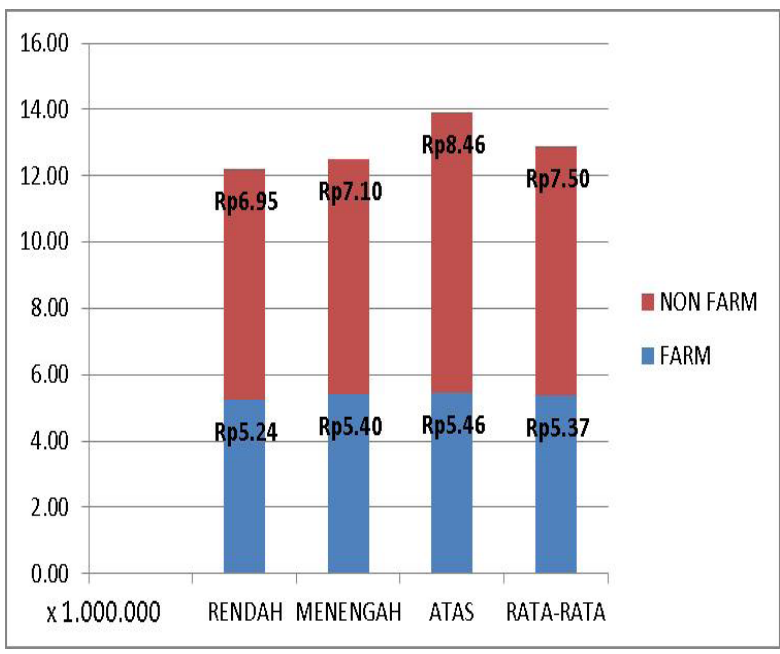

Gambar 2. Struktur pendapatan rumahtangga petani rata-rata per tahun menurut lapisan di Desa Ngeposari Tahun 2015

Masyarakat Desa Sungai Aur memang sebagian besar bekerja di sektor pertanian, atau sekitar $33.28 \%$. Sektor pertanian memang menjadi salah satu tumpuan dari Masyarakat Desa Sungai Aur, komoditi andalan terbesar yang dihasilkan dari desa Sungai Aur adalah Kadelai dan Jagung. Hal ini dikarenakan kondisi tanah Desa Sungai Aur yang yang tidak terlalu basah, namun ketersediaan air tetap terjaga. Jagung merupakan tanaman indikator yang baik bagi kedelai. Tanah yang baik ditanami jagung, baik pula ditanami kedelai. Bahkan pada tahun 2014, hasil produksi pertanian komoditas kedelai merupakan salah satu yang terbaik di seluruh Provinsi Jambi dengan hasil produksi sebesar 75 Ton. Pola tanam yang diterapkan oleh masyarakat sangat dinamis karena harus mampu beradaptasi dengan berbagai "ancaman" alam yang terjadi setiap tahun. Bencana alam yang tiap tahun terus menerus mengancam ekosistem dan penghidupan masyarakat lokal adalah banjir dan kebakarakan hutan. Baik banjir yang meluap dari Sungai Batanghari serta anak sungainya, maupun kebakaran yang muncul akibat disengaja (land clearing) ataupun tidak disengaja (kemarau panjang). Umumnya banjir terjadi di bulan November - Desember, sedangkan kebakaran di bulan Juli - Oktober.

Pada dasarnya, sektor pertanian bukan merupakan sektor asli mata pencaharian masyarakat Desa Sungai Aur. Masyarakat Desa Sungai Aur dalam sejarahnya lebih memanfaatkan sumber daya alam sebagai sumber penghidupan, seperti sungai dan hutan. Desa Sungai Aur merupakan salah satu desa yang tepat bersebelahan dengan Sungai Batanghari, dimana di sekitarnya terdapat kawasan hutan yang masih primer dan terbentang sangat luas. Namun pada saat ini agroekosistem Desa Sungai Aur terus berubah seiring perkembangan Zaman. Demikian halnya dengan dinamika kependudukan, pada awalnya seluruh masyarakat Desa Sungai Aur adalah penduduk asli yang merupakan suku Melayu Jambi, namun sejak masuknya berbagai perusahaan logging, orang dari luar desa mulai berdatangan untuk mencoba peruntungan dan pada akhirnya menetap di desa.

\section{HASIL DAN PEMBAHASAN}

\section{Struktur Nafkah dan Potensi Karbon di Desa Ngeposari, DIY}

Kepemilikan lahan di Desa Ngeposari pada dasarnya dapat dibagi menjadi kepemilikan pribadi atau kepemilikan lahan 


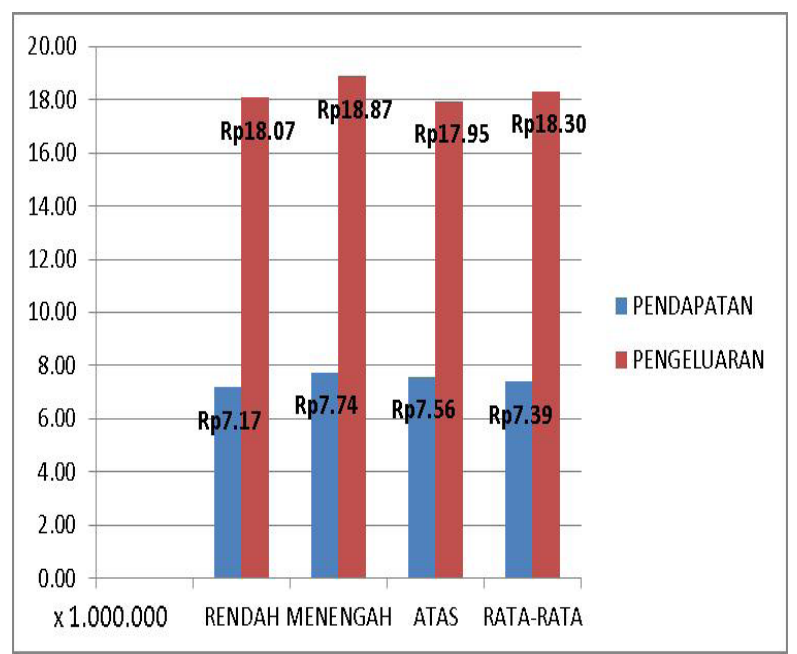

Gambar 3. Struktur nafkah rata-rata rumahtangga responden menurut golongan di Desa Ngeposari

dalam HKm. Kepemilikan lahan dalam HKm pada akhirnya akan sangat berkaitan dengan potensi perolehan karbon yang akan "dibagikan" (karena berdasarkan pada asumsi luas lahan). Berikut tabel frekuensi dan presentase luas lahan HKM di Desa Ngeposari, Kecamatan Semanu, Kabupaten Gunung Kidul DIY Pada Tahun 2015.

Berdasarkan data luas lahan HKM maka dapat dapat diketahui bahwa tiga puluh tujuh persen petani memiliki luas lahan HKM dengan kategori sempit. Menurut penuturan ketua kelompok Sedyo Makmur, pembagian luas lahan HKM berdasarkan kemampuan anggota dalam mengolahnya. Kemampuan anggota tersebut dinilai dari segi ekonomi rumahtangga petani. Maka dapat disimpulkan bahwa mayoritas rumahtangga petani di Desa Ngeposari masih berada dalam ekonomi bawah. Hal ini akan dijelaskan lebih lanjut dalam struktur pendapatan rumahtangga petani.

Struktur Pendapatan rumahtangga petani di Desa Ngeposari dibagi ke dalam dua bagian, yaitu struktur pendapatan Farm dan Struktur Pendapatan Non Farm. Struktur pendapatan Farm dihitung berdasarkan hasil pertanian seperti kedelai, jagung, ketela, dan kacang. Sedangkan struktur pendapatan non farm dihitung berdasarkan hasil dari berdagang, PNS, transfer payment, dan buruh bangunan. Berikut struktur pendapatan Farm dan Non Farm di Desa Ngeposari Tahun 2015.

Berdasarkan Gambar 2 di atas dapat diketahuistruktur pendapatan rumahtangga petani di Desa Ngeposari, Kecamatan Semanu, Kabupaten Gunung Kidul, DIY. Sektor Farm sebanyak 27 rumahtangga berada di lapisan bawah dengan pendapatan dari sektor Farm sebesar Rp. 5.24 Juta/ tahun. Jumlah tersebut tentu sangat sedikit karena pendapatan dari sektor farm sudah sangat menurun. Penurunan ini diakibatkan pohon jati yang sudah besar dan sudah harus dipanen mengurangi produktivitas tanaman palawija yang ditanam di bawahnya. Sebanyak 24 rumahtangga di sektor Farm termasuk dalam golongan menengah dengan pendapatan Rp. 5.4 juta/tahun. Jumlah ini tidak terlalu jauh berbeda dengan golongan bawah karena sebab yang sama. Sebanyak 19 rumahtangga di sektor Farm termasuk dalam golongan atas dengan pendapatan sebesar Rp. 5.46 juta/tahun. rumahtangga petani di Desa Ngeposari sudah tidak mampu lagi bergantung pada sektor Farm karena hasil sudah sangat menurun sejak 10 tahun terakhir.

Dalam sektor non farm, sebanyak 32 rumahtangga petani

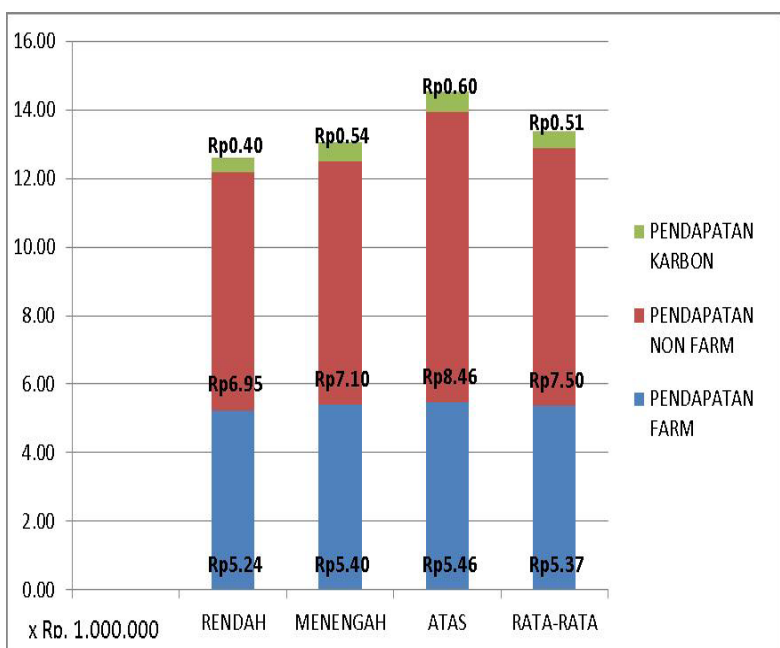

Gambar 4. Struktur Nafkah On Farm, Off Farm dan Karbon Asumsi Pertama

termasuk golongan bawah dengan pendapatan Rp. 6.95 juta/ tahun. Rumahtangga golongan bawah dalam sektor non farm bekerja sebagai buruh bangunan atau berdagang kecil-kecilan. Sebanyak 21 rumahtangga petani termasuk golongan menengah dengan pendapatan Rp. 7.10 juta/tahun. Rumahtangga petani golongan menengah ini bermatapencaharian sebagai pedagang skala menengah atau mengandalkan transfer payment dari anak-anak mereka. Sebanyak 17 rumahtangga petani dalam sektor non farm termasuk dalam golongan atas. Rumahtangga tersebut bekerja sebagai PNS atau perangkat desa. Dalam struktur nafkah rumahtangga petani di Desa Ngeposari dapat dilihat pendapatan dan pengeluaran rumahtangga petani. Berikut adalah struktur nafkah rumahtangga petani di Desa Ngeposari menurut golongan pada tahun 2015.

Struktur pengeluaran rumah tangga para petani dihitung berdasarkan pengeluaran pokok untuk pangan, sandang, dan papan serta modal usaha tani. Pengkategorian struktur pengeluaran berdasarkan kurva sebaran normal. Berikut struktur pengeluaran rumahtangga petani di Desa ngeposari tahun 2015.

Sebanyak 25 rumahtangga petani Desa Ngeposari diketahui memiliki pengeluaran dengan kategori rendah. Sebanyak 28 rumahtangga petani di DesaNgeposari memiliki pengeluaran dengan kategori sedang. sebanyak 17 rumahtangga petani di Desa Ngeposari memiliki pengeluaran dengan kategori tinggi. Berdasarkan data tersebut maka dapat disimpulkan bahwa sebagian besar rumahtangga petani di Desa Ngeposari memiliki struktur pengeluaran di tingkat sedang.

Berdasarkan Gambar 10 di atas, dapat diketahui bahwa gap yang terjadi antara pendapatan dan pengeluaran rumahtangga petani cukup jauh. Hal ini menunjukkan bahwa terdapat strategi lain yang digunakan rumahtangga untuk mencukupi kebutuhan sehari-hari. Pada saat penelitian ini dilakukan, pendapatan rumahtangga petani dari sektor farm memang sedang mengalami penurunan. Penurunan tersebut diakibatkan rendahnya produktivitas tanaman palawija yang menjadi andalan petani. Hasil tanaman palawija tersebut menurun karena pohon jati sudah besar dan harus sudah dipanen.

Penghitungan sumbangan ekonomi karbon bagi rumahtangga petani merupakan inti dari keseluruhan bab ini. Setelah memahami luas lahan dan struktur nafkah rumahtangga petani, maka dapat diketahui tingginya ketergantungan petani terhadap lahan HKM. Namun, sejauh ini insentif yang didapatkan petani hanya berupa hasil dari tanaman palawija.. 


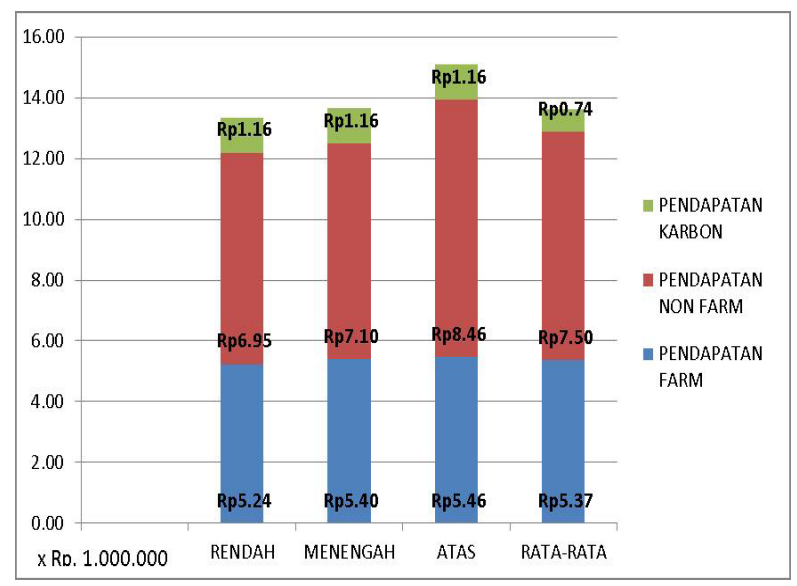

Gambar 5. Struktur Nafkah On Farm, Off Farm dan Karbon Asumsi Kedua

Hingga saat ini, LSM Shorea sudah menghitung jumlah karbon yang dihasilkan oleh lahan HKM Kelompok Sedyo Makmur. Namun, belum ada skema benefit sharing dengan langsung memasukan harga pasaran karbon di dunia.

Penghitungan karbon dilakukan dengan menggunakan tiga asumsi. Asumsi pertama yaitu berdasarkan skema bagi hasil dari kelompok Sedyo Makmur dimana rumahtangga petani mendapatkan 60 persen, lalu kelompok mendapatkan 40 persen dari hasil penjualan karbon. Kemudian dari 60 persen tersebut dibagi berdasarkan luas lahan yang dimiliki masingmasing lapisan rumahtangga petani, diperolah sata sebagai berikut.

Berdasarkan Gambar 4 di atas, maka dapat diketahui bahwa sumbangan ekonomi karbon dengan menggunakan asumsi pertama tidak jauh berbeda antara rumahtangga lapisan atas, menengah, dan bawah. Sumbangan ekonomi karbon berkisar pada angka 510 ribu rupiah untuk setiap rumahtangga. Jumlah ini tentu saja sedikit karena hasil penjualan karbon tidak seratus persen untuk rumahtangga petani. Selain itu, luas lahan HKM yang dikelola masing-masing rumahtangga juga mempengaruhi hasil yang diterima. Rumahtangga dengan lahan yang cukup luas akan mendapatkan uang yang lebih banyak, begitupun sebaliknya.

Asumsi kedua yaitu tidak menggunakan skema bagi hasil kelompok Sedyo Makmur, yaitu seratus persen hasil penjualan untuk rumahtangga dibagi sama rata tanpa memperhatikan luas lahan. Maka diperoleh hasil sebagai berikut.

Berdasarkan Gambar 5 di atas, maka dapat diketahui bahwa tanpa 1,16 juta rupiah. Asumsi kedua ini dianggap kurang adil karena jumlah luas lahan yang dikelola oleh rumahtangga petani kelompok Sedyo Makmur berbeda-beda. Luas lahan tersebut akan mempengaruhi modal awal dan pengelolaan hutan jati tersebut. Jika asumsi kedua ini mengganggap rumahtangga yang mengelola 1,5 Ha sama dengan rumahtangga yang mengelola $0,25 \mathrm{Ha}$ mendapatkan hasil yang sama.

Asumsi ketiga yaitu penghitungan tidak mengikuti skema bagi hasil kelompok Sedyo Makmur, namun seratus persen hasil penjualan karbon yang diperolah diberikan ke rumahtangga petani anggota kelompok dengan memperhatikan luas lahan. Maka didapatkan hasil berikut

Berdasarkan Gambar 6 di atas, maka dapat diketahui bahwa sumbangan ekonomi karbon yang diperoleh rumahtangga cukup besar, yaitu sekitar 1,82 juta rupiah. Jumlah ini tentu

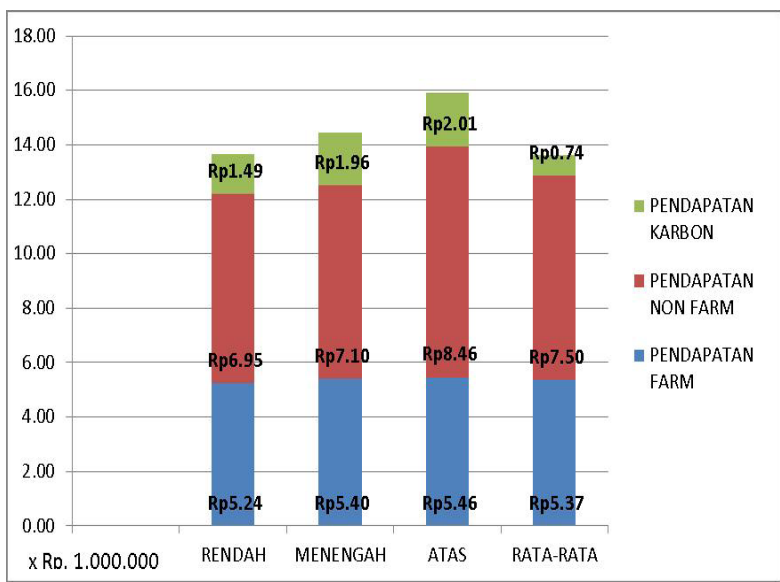

Gambar 6. Struktur Nafkah On Farm, Off Farm dan Karbon Asumsi Ketiga

saja lebih besar dari asumsi pertama dan kedua karena tidak mengikuti skema bagi hasil kelompok Sedyo Makmur. Jumlah yang diperoleh masing-masing rumahtangga lapisan bawah, menengah, dan atas tidak berbeda jauh.

\section{Struktur Nafkah dan Potensi Karbon di Desa Sungai Aur,} Provinsi Jambi

Posisi Desa Sungai Aur yang berada di sekitar taman nasional dan di kawasan TAHURA merupakan potensi besar untuk pengembangan program karbon. Terlebih lagi menghadapi tantangan ekspansi perkebunan kelapa sawit yang kuat baik yang dilakukan oleh perusahaan maupun secara individual. Kondisi tanah yang berupa tanah gambut juga menjadi permasalahan jika pengembangan perkebunan dilakukan tanpa menggunakan teknik pengolahan tanah dan irigasi yang baik.

Desa Sungai Aur merupakan Desa yang sebagian besar masyarakatnya masih menggantungkan sumber penghidupannya pada sektor pertanian (dalam artian luas). Terkait hal tersebut, luas kepemilikan lahan pada akhirnya berimplikasi pada juga pada struktur nafkah atau pendapatan serta pengeluaran mereka. Secara garis besar, pendapatan dapat diklasifikasikan menjadi sektor farm (pertanian) dan non-farm (diluar pertanian). Berikut data yang menggambarkan kondisi pendapatan pada masyarakat Desa Sungai Aur pada tahun 2015.

Berdasarkan Gambar 7, dapat diketahui bahwa pelapisan masyarakat antara lapisan bawah hingga tinggi memiliki perbedaan yang cukup berarti. Pada lapisan bawah, umumnya mereka mereka menggantungkan penghidupannya pada sektor non-farm seperti menjadi buruh kasar serta buruh pertanian, hasil pertanian mereka tidak cukup menjanjikan sebagai penopang kebutuhan sehari-hari. Sehingga umumnya hasil pertanian yang mereka produksi hanya sebatas untuk kebutuhan subsistensi (karena faktor lahan sempit dan mahalnya harga pestisida sehingga produksi tidak dapat maksimal). Berbeda dengan lapisan menengah, hasil pertanian pada dasarnya dapat digolongkan pada produksi yang cukup optimal.

Demikian dengan kontribusi sektor non-farm, jika dilihat di Desa Sungai Aur mereka yang masuk pada golongan ini adalah mereka yang umumnya bekerja di luar desa, sektor formal serta wirausaha skala-menengah bawah (seperti beberapa responden yang mulai berjualan pulsa, memperbaiki pakaian, dst). Sedangkan untuk masyarakat lapisan atas, mereka pada umumnya dapat diketahui dari kepemilikan lahan tinggi yang 


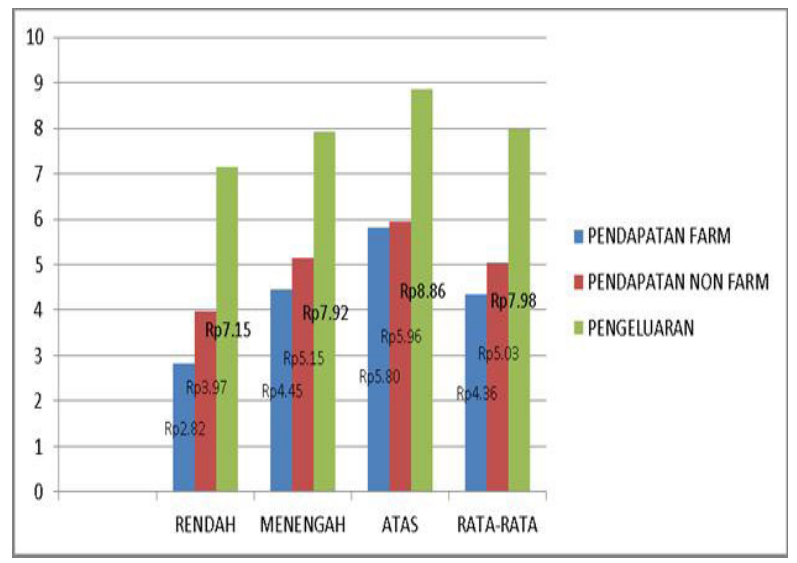

Gambar 7. Struktur Pendapatan Pertanian dan Non-Pertanian di Desa Sungai Aur

dibarengi oleh wirausaha skala menengah bawah (atau salah satunya). Bagi masyarakat lapisan atas, kontribusi pertanian cukup optimal karena mereka tidak memiliki kendala dari aspek finansial, terlebih dalam menghadapi dinamika iklim belakangan ini, masyarakat pada lapisan atas cenderung dapat melenting dengan bantuan modal ekonominya untuk memperbaiki lahan mereka dan memperkerjakan buruh. Masyarakat lapisan atas yang menjadi anggota Kelompok Konservasi Pengelola Tahura juga diuntungkan dengan hasil produksi buah-buahan yang baik, seperti buah Jeruk hingga cokelat. Namun kemarau pada belakangan ini mulai menimbulkan permasalahan baik pada lapisan bawah maupun atas, namun pada lapisan atas mereka mulai merasakan dampak negatif yang besar akibat keringnya jalur kanal (sehingga menghambat pengangkutan hasil perkebunan) hingga kebakaran hutan yang terus mengancam di sekitar perkebunan mereka.

Terkait dengan dinamika perubahan iklim, kondisi tersebut juga ternyata berpengaruh dalam struktrur pengeluaran masyarakat Desa Sungai Aur. Bencana alam yang tiap tahun terus menerus mengancam ekosistem dan penghidupan masyarakat lokal adalah banjir dan kebakarakan hutan. Baik banjir yang meluap dari Sungai Batanghari serta anak sungainya, maupun kebakaran yang muncul akibat disengaja (land clearing) ataupun tidak disengaja (kemarau panjang). Umumnya banjir terjadi di bulan November - Desember, sedangkan kebakaran di bulan Juli - Oktober. Kondisi tersebut menunjukkan bagaimana masyarakat harus mampu mengantisipasi dan berhadapan dengan pola bencana tahunan yang mengancam berbagai aset milik mereka. Bencana banjir dan kebakaran sangat mengancam lahan pertanian dan rumah mereka (karena Desa Sungai Aur terletak tepat bersebelahan dengan Sungai Batanghari, dan di sebelah timurnya terdapat hutan dari TAHURA yang tiap tahunnya menjadi titik-titik api).

Pada akhirnya tingkat pengeluaran Masyarakat Desa Sungai Aur menjadi meningkat tiap tahunnya, kondisi ini bahkan mengancam eksistensi pendapatan sektor pertanian mereka. Karena jika musim kemarau tiba, api yang muncul sangat sulit dipadamkan dan jika sudah merembet hingga lahan pertanian warga cenderung membiarkannya dan menyerahkannya pada instansi terkait. Karena menurut beberapa informan, api dalam skala besar akan sangat sulit dipadamkan jika hanya menggunakan ember dan sejenisnya, terkecuali titik api masih kecil dan dapat terkontrol. Hal tersebut pada akhirnya menyebabkan pengeluaran masyarakat meningkat, karena

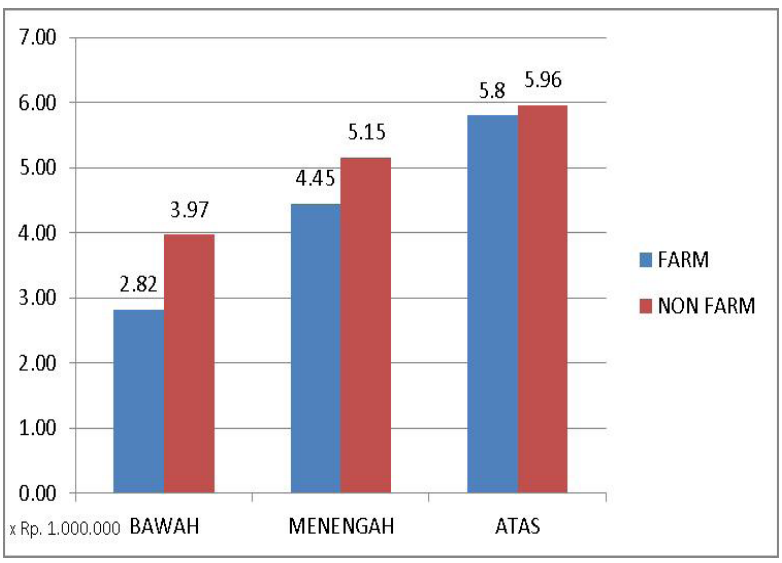

Gambar 8. Struktur Pendapatan Pertanian dan Non-Pertanian serta Pengeluaran Responden di Desa Sungai Aur,

ada bencana alam menghasilkan negative cost bagi peluang produksi mereka. Seperti dapat dilihat pada gambar berikut:

Berdasarkan Gambar 8, dapat diketahui bahwa tingkat pengeluaran pada dasarnya cukup besar pada tiap lapisan. Terlebih pada lapisan bawah dimana selisih antara pendapatan dan pengeluarannya yang lebih besar pengeluaran, hal ini dikarenakan mereka merupakan lapisan yang paling rentan namun menerima keterpaparan yang tinggi dari dampak negatif bencana alam. Pengeluaran tersebesar hampir pada setiap lapisan lebih menyangkut pada aspek "perbaikan", baik itu dalam sektor pertanian maupun perumahan. Khususnya untuk lapisan sedang dan bawah, dimana beberapa responden menyebutkan bahwa pengeluaran terbesarnya tahun ini adalah untuk mempersiapkan lahan untuk ladang (membersihkan lahan) serta keperluan produktivitas pertanian lainnya.

Sedangkan untuk lapisan atas, pengeluaran besar salah satunya dikarenakan kebakaran hutan yang mulai melanda belakangan ini. Salah satu responden menyebutkan kebun sawit miliknya (sekitar $1.8 \mathrm{ha}$ ) dan beberapa tetanggannya terbakar habis akibat rembetan api yang berasal dari tengah hutan. Kerugian tersebut tentu saja tidak hanya menyebabkan kerugian dari produk pertanian yang terbakar, namun juga pasca-kebakaran dimana lahan harus kembali dibersihkan dan ditanami.

Sebagai salah satu bentuk antisipasi dan dialektis dari negative cost yang dihasilkan oleh berbagai bencana alam. Skema perdagangan karbon menjadi salah satu opsi yang potensial untuk diterapkan dalam kawasan TAHURA. Dengan skema perdangangan karbon yang inklusif dan melibatkan masyarakat, masyarakat lokal tidak hanya dapat menjaga ekosistem, namun juga menambah pendapatan bagi sistem nafkah mereka. Skema pendapatan karbon dari TAHURA telah dikonstruksikan dengan pendekatan di lapang, dan didapati bahwa dari total luas TAHURA yang sebesar 20.860 ha kawasan hutan di dalamnya adalah seluas 7977.02 ha. Dari luas kawasan hutan tersebut, didapati karbon sebesar 54.515 ton (c) / ha dan jika diasumsikan total karbon selama 20 tahun maka total karbon yang dapat dihasilkan adalah 1095241.14. Atau dengan hasil sebagai berikut:

Berdasarkan Gambar 9, dapat diketahui bahwa karbon dapat memberikan manfaat ekonomi (walaupun tidak dalam skala yang begitu besar) jika mampu dikelola dan didistribusikan dengan prinsip keseimbangan dan berkeadilan. Skema tersebut muncul dengan asumsi sebagai berikut:

1. Kontribusi karbon yang diterima berdasarkan Hutan dalam TAHURA yang sebesar 7977.02 ha (sekitar 1/3 


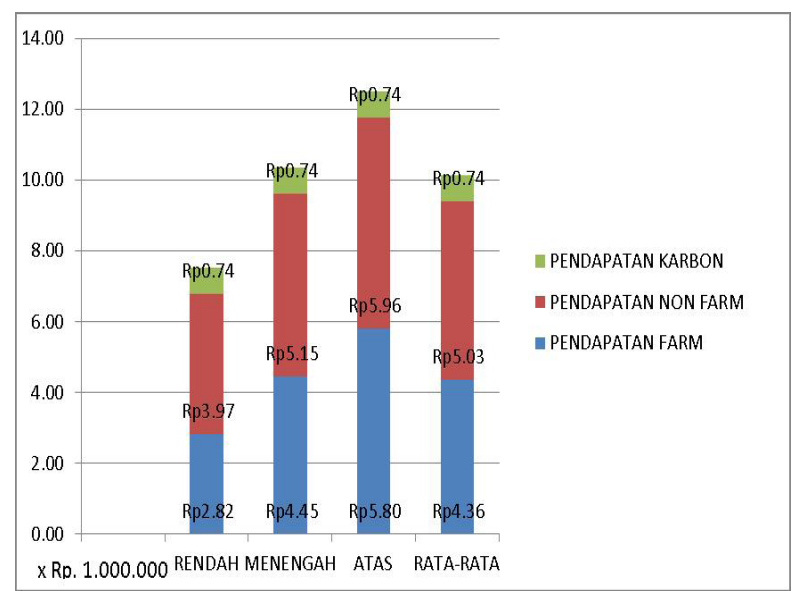

Gambar 9. Struktur Pendapatan Pertanian dan Non-Pertanian serta Pendapatan Karbon di Desa Sungai Aur

dari luas total TAHURA) adalah Rp. 54,104,912,544 / 20 tahun. Atau jika dibagi dalam hitungan tahun, maka nominal yang dapat diperoleh adalah Rp. 2,705,245,627 / tahun.

2. Terdapat tujuh desa / kelurahan yang terletak bersebelahan (dan tumpang tindih) dalam kawasan TAHURA. Desa / Kelurahan tersebut adalah: (1) Desa Sungai Aur; (2) Desa Jebus; (3) Desa Gedong Karya; (4) Kelurahan Tanjung; (5) Desa Seponjen; (6) Desa Sungai Bungur; dan (7) Desa Pematang Raman. Masing-masing desa setidaknya "memiliki" lahan di dalam TAHURA sekitar $2.000-$ 3.000 ha. Berdasarkan data tersebut, maka apabila asumsi total keuntungan sebesar Rp. 2,705,245,627 / tahun dan dibagi ke tujuh desa yang bersebelahan, maka akan didapati angka Rp. 386,463,661.03 / tahun / desa.

3. Jika keuntungan yang diperoleh Desa Sungai Aur sebesar Rp. 386,463,661.03 / tahun, maka jika asumsinya dibagi sama rata dengan seluruh kepala keluarga di Desa Sungai Aur yang berjumlah $516 \mathrm{KK}$ (tanpa pertimbangan lain), maka masing-masing $\mathrm{KK}$ akan mendapat nominal sejumlah Rp. 748,960.58.

4. Asumsi laju deforestasi adalah $3.1 \%$. Kondisi ini juga dibangun dengan faktor-faktor lainnya seperti illegal logging, kebakaran hutan, dan alih fungsi lahan yang berada dalam kondisi stabil atau terjaga

\section{Dinamika Kelembagaan dan Kesiapan Dalam Isu Karbon Berbasis Masyarakat}

Isu karbon di kedua lokasi tersebut menemukan dua persoalan yang juga berbeda, kawasan DIY memiliki dinamika yang jauh lebih kompleks dalam aspek legalitas serta pasar penjualan karbon, sedangkan kawasan Jambi dalam aspek pelibatan masyarakat serta skema pengelolaan yang masih "mentah" dan belum mengarah langsung pada isu karbon. Kedua lokasi tersebut setidaknya menggambarkan dua persoalan yang berbeda di tataran yang berbeda, atau secara singkat seperti yang dijelaskan dalam Gambar 10.

Berdasarkan Gambar 10, dapat diketahui bahwa inisiasi awal terkait dengan pengelolaan kawasan hutan di kedua lokasi sama-sama diinisiasi oleh LSM, untuk di wilayah DIY diinisiasi oleh LSM SHOREA, sedangkan untuk di wilayah Jambi diinisiasi oleh LSM Gita Buana. Namun perbedaan dinamika dan permasalahan yang dihadapi di kedua lokasi pada akhirnya berimplikasi terhadap sistem pendekatan dan pengkonstruksian kelembagaan yang berbeda. Untuk

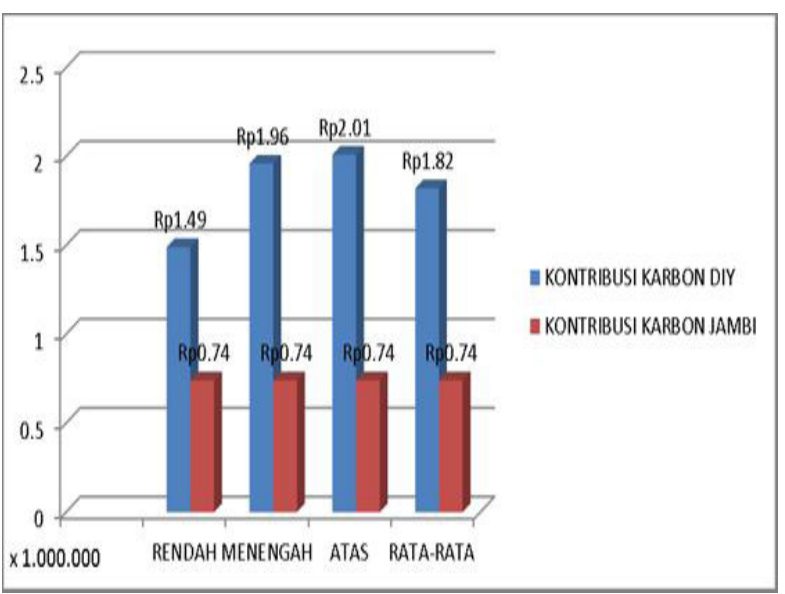

Gambar 10. Aspek Pembanding Isu Karbon di DIY dan Jambi

di wilayah DIY, LSM melakukan pendampingan hingga pelatihan terhadap satu kelompok tani (Kelomok Tani Hutan Sedyo Makmur) yang anggotanya merupakan warga di dua desa, dan sebagian warga tersebut terlibat dalam kelompok tani. Sedangkan untuk di wilayah Jambi, LSM hanya melakukan pendampingan secara terbatas terhadap kelompok tani kecil yang sudah terlebih dahulu mengelola lahan di dalam TAHURA. Kelompok tersebut hanya terdiri dari 16 - 25 orang, namun pendekatan tersebut menurut pihak LSM paling tepat karena mempertimbangkan kawasan TAHURA yang masih penuh dengan kepentingan perambah. Berbeda dengan kelembagaan di DIY yang sudah berada pada tahap inklusif dan memiliki kohesivitas tinggi, di Kawasan Jambi, kelembagaan masih berada pada tahap penguatan awal, sehingga perlu dibangun secara perlahan untuk merangkul seluruh pihak yang saling berkaitan, sehingga masih belum tercapai tahap inklusif dan kohesivitas yang tinggi.

Pembahasan selanjutnya berkaitan dengan legalitas hutan yang dimanfaatkan. Hutan di DIY dikelola oleh masyarkat secara legal melalui hak pengelolaan hutan kemasyarakatan $(\mathrm{HKm})$, namun kondisi tersebut berbanding terbalik dengan legalitas hutan yang dimanfaatkan di Jambi yang sepenuhnya milik negara. Kondisi tersebut yang pada akhirnya juga berimplikasi secara khas terhadap tanaman yang ditanam oleh kedua masyarakat tersebut.Masyarakat di DIY menanam tanaman keras seperti Pohon Jati yang memang ditujukkan untuk investasi jangka panjang, disekitar pohon utama tersebut juga ditanami tanaman tumpang sari. Sedangkan untuk di lokasi Jambi, penanaman tanaman keras belum dilakukan, tanaman masih sebatas tanaman yang hasilnya dapat dimanfaatkan oleh masyarakat dalam waktu yang cukup cepat, seperti buah-buahan serta sayur-mayur. Hal tersebut menunjukkan bagaimana legalitas lahan pada akhirnya dapat berpengaruh terhadap komoditas atau jenis tanaman yang ditanam, yang pada akhirnya berkaitan juga dengan upaya pelibatan masyarakat dalam aktivitas jasa lingkungan.

Dinamika pengelolaan kawasan hutan di kedua lokasi secara keseluruhan menunjukkan dua kondisi yang berbeda, di kawasan Jambi pada saat ini masih berada dalam upaya "pembentukan kelembagaan", masyarakat dikenalkan dengan cara dan metode baru yang merupakan anti-tesis berbagai program non-partisispatif dan sebatas menjadikan masyarakat sebagai objek. LSM Gita Buana mencoba memposisikan masyarakat sebagai subjek, diantaranya dengan cara pelibatan penuh masyarakat, baik dari tahap pelatihan, bantuan hingga 


\begin{tabular}{|c|c|c|}
\hline ASPEK PEMRANDING & $\begin{array}{c}\text { DAERAH ISTMMEWA } \\
\text { YOGYAKARTA }\end{array}$ & JAMRI \\
\hline Inisiasi Awal & LSM & LSM \\
\hline Keterlibatan & $\begin{array}{c}\text { Luas - LSM berkolaborasi dengan } \\
\text { Kelompok Tani di Tingkat Desa }\end{array}$ & $\begin{array}{c}\text { Terbatas - LSM mendampingi satu } \\
\text { kelompok kecil di Tingkat Desa }\end{array}$ \\
\hline Property Rights & $\begin{array}{c}\text { Milik Negara yang dikelola } \\
\text { Masyarakat (Hutan } \\
\text { Kemasayrakatan) }\end{array}$ & $\begin{array}{c}\text { Milik Negara yang dikelola Negara, } \\
\text { namun dapat melibatkan } \\
\text { Masyarakat }\end{array}$ \\
\hline Fisik - Spasial & Batas dan Kepemilikan jelas & Batas dan Kepemilikan tidak jelas \\
\hline Fisik - Tanaman Keras & Pohon Jati & - \\
\hline Fisik - Tanaman Sekunder & Kedelai, Umbi-Umbian, dsj. & Tanaman Buah, Petai, dsj. \\
\hline
\end{tabular}

Gambar 11. Struktur Pendapatan Pertanian dan Non-Pertanian serta Pendapatan Karbon di DIY dan Jambi

pendampingan. Proses yang dibangun di Jambi juga dilakukan dengan upaya merubah "pola pikir", bahwa masyarakat yang mengelola lahan di kawasan hutan harus juga berfungsi sebagai penjaga hutan untuk menghindari aksi illegal logging yang masih marak pada saat ini. Walaupun akhirnya kawasan hutan TAHURA kerap dianggap open access bagi sebagian pihak, tetapi sebetulnya yang terjadi adalah pendekatan partisipatif dan lebih realistis dalam menutup kemungkinan perambahan yang lebih ekspansif dari masyarakat lokal atau para pendatang luar desa dengan pelibatan komunitas yang sudah membangun jaringan dan modal terlebih dahulu di dalam kawasan tersebut. Kondisi yang lebih siap dalam mengusung masyarakat berbasis karbon ditunjukkan di kawasan DIY. Kesiapan tersebut dapat terlihat dalam aspek kelembagaan hingga pengaturan tanaman (dengan menerapkan jarak tanam pengaturan blok dsb). Bahkan Kelompok Tani Hutan Sedyo Makmur juga sudah mulai mengenal "skema' perdagangan karbon yang dapat diterapkan dengan pola community to government / business. Selain itu, dengan kepemilikan hutan yang jelas serta pendataan lingkar tanaman dan pengaturan hutan dalam blokblok khusus jelas dapat memudahkan "pembeli karbon” untuk melakukan transaksi dan pembayaran jasa lingkungan. Hanya saja persoalan saat ini mereka masih belum mampu menjamah pasar dan memeperoleh pembayaran jasa lingkungan yang sudah mulai mereka lakukan sejak belasan tahun lalu. Pada akhirnya dapat diketahui bahwa kawasan DIY dengan lebih siap menghadapi pasar karbon dengan skema Voluntary Carbon Market, walaupun masih ada beberapa kendala eksternal yang harus diperbaiki dan dibangun bersama dengan stakeholders terkait. Sedangkan kawasan Jambi dapat terbilang masih cukup jauh mengusung masyarakat berbasis karbon, selain persoalan kelembagaan dan dinamika kawasan yang lebih kompleks, jika ditarik pada tingkat provinsi, isu REDD + juga nampaknya mengalami stagnansi karena ketidakjelasan pengelolaan serta nomenklatur.

\section{KESIMPULAN DAN SARAN}

\section{Kesimpulan}

Berdasarkan pemaparan diatas, maka dapat diketahui bahwa terdapat beberapa perbedaan terkait struktur nafkah dan kontribusi karbon pada lokasi penelitian di Desa Ngeposari, Kecamatan Semanu Kabupaten Gunung Kidul, DIY dengan di Desa Ngeposari, Kecamatan Kumpeh, Provinsi Jambi.

Untuk di Desa Ngeposari, kawasan HKm seluas 115 ha telah dikelola oleh Kelompok Sedyo Makmur dengan didampingi oleh:LSM Shorea dalam berbagai prosesnya, hingga proyeksi serta pelatihan pengukuran karbon. Mekanisme perdagangan karbon sudah di konstruksikan dan bahkan potensi karbon sudah dihitung sejak tahun 2012 dan dibuat proyeksinya hingga tahun 2020 .

Sedangkan untuk di Desa Sungai Aur, kawasan atau lahan TAHURA yang terletak di sekitar desa yang seluas 20.860 ha dikelola sepenuhnya oleh Pemerintah Provinsi Jambi (sejak tahun 2013 pengelolaan secara khusus dikelola oleh UPTD TAHURA), masyarakat pada saat ini sama sekali tidak dapat menggunakan atau memanfaatkan berbagai sumber daya alam yang terdapat di dalamnya. Berdasarkan data yang diperoleh di dua lokasi tersebut, maka simpulan yang dapat diambil adalah: Desa Ngeposari sudah memiliki basis kelembagaan dalam skema karbon VCM (Voluntary Carbon Market) yang cukup mumpuni namun belum menerima manfaat apapun dari aktivitas tersebut. Berbeda dengan di Desa Sungai Aur yang masih sangat awam dengan kerangka perdagangan karbon atau pengelolaan kawasan hutan. Berbeda dengan di Desa Ngeposari, skema perdagangan karbon yang memungkinkan diimplementasikan adalah skema Government to Government. Kontribusi karbon di Desa Ngeposari diperoleh dari HKm yang seluas 115 ha, jika total kontribusi karbon tersebut selanjutnya dibagi jumlah anggota HKm yang sebanyak 254 KK (dengan skema bagi $100 \%$ berdasarkan luas lahan) maka nominal yang diperoleh adalah sebesar Rp. 1,820,000 / kk / tahun. Sedangkan untuk Desa Sungai Aur, nominal yang diperoleh dihasilkan dari kawasan hutan di dalam TAHURA yang seluas 7,977 ha, jika dibagi jumlah KK di desa sebanyak 516 KK (dengan skema bagi 100\% dengan asumsi sama rata) maka nominal yang diperoleh adalah Rp. 748,960.58 / kk / tahun. Selisih pendapatan yang dapat dihasilkan dari kedua lokasi tersebut adalah Rp. 1.071.040 / tahun dengan selisih luas lahan 7,888. Atau seperti dapat dilihat pada gambar.

Setelah didistribusikan dalam struktur nafkah masyarakat secara keseluruhan, kontribusi karbon ternyata dianggap dapat mampu meningkatkan pendapatan masayrakat walaupun masih dalam skala yang kecil (khususnya dalam skema VCM; karena kesepakatan harga / lainnya tidak ditentukan mutlak oleh pasar). Kondisi tersebut berarti mengisyaratkan perlu adanya pengelolaan karbon yang lebih komperhensif dan berkeadilan, dengan mengedepankan konsep benefit sharing yang mampu menjamah ke segala lapisan masyarakat 
Rounsevell MDA, Williams M. 2014. Understand-

Penelitian tahap pertama telah mengidentifikasi bahwa ada potensi untuk pengembangan inisiatif karbon berbasis masyarakat dan kesadaran masyarakat untuk berpartisipasi dalam pengembangan tersebut. Permasalahannya adalah carbon trading tidak seperti perdagangan produk kehutanan berupa kayu yang pangsa pasarnya terbuka luas. Oleh karena itu, sesuai dengan rencana penelitian yang dilakukan dalam dua tahap, pada tahap kedua lebih didorong untuk melihat potensi pengembangan kemitraan antara kelembagaan produsen karbon di tingkat masyarakat dan targe konsumen. Selain itu, keterlibatan pemerintah juga menjadi penting.

Dalam hal ini menjadi penting penelitian tahap kedua untuk dilanjutkan pada tingkat supra lokal. Selaian penelitian perlu juga melakukan studi banding pada beberpa model VCM yang sudah berhasil dan sudah ada di Indonesia sehingga model pengembangan kemitraan perdagangan karbon berbasis masyarakat dapat terwujud.

\section{DAFTAR PUSTAKA}

Agung P. 2010. Inisiasi Kebijakan REDD di Indonesia; Menunggu Asa atau Masalah. [internet]. Diunduh pada: 18/10/2015. Dapat diunduh dari: http://fwi.or.id/publikasi/inisiasi-kebijakan-redd-di-indonesia-menunggu-asa-atau-masalah/

Agrawal A, Wollenberg E, Persha L. 2014. Governing agriculture-forest landscapes to achieve climate change mitigation. Global Environmental Change. Vol. 28: 270-280. DOI: 10.1016/j.gloenvcha.2014.10.001

Boyd E, Gutierrez M, Chang M. 2006. Small-scale forest carbon projects: Adapting CDM to low-income communities. Global Environmental Change. Vol. 17: 250-259. DOI: 10.1016/j.gloenvcha.2006.10.001

Brown D, Seymour F, Peskett L. 2008. How do we achieve REDD co-benefits and avoid doing harm. Moving ahead with REDD: issues, options and implications. [internet]. Dapat diunduh dari: http://www.cifor.org/ publications/pdf_files/Books/BAngelsen080111.pdf

Collier N, Campbell BM, Sandker M, Garnett ST, Sayer J, Boedhihartono AK. 2011. Science for action: the use of scoping models in conservation and development. Environmental Science \& Policy. Vol. 14: 628 - 638. DOI: 10.1016/j.envsci.2011.05.004

Caplow S, Jagger P, Lawlor K, Sills E. 2011. Evaluating Land Use and Livelihood Impacts of Early Forest Carbon Projects: Lessons for Learning about REDD+. Environmental Science \& Policy. Vol. 14: 152-167. DOI: 10.1016/j.envsci.2010.10.003

Dharmawan AH. 2001. Farm Household Livelihood Strategies and Socio-economic Changes in Rural Indonesia. [internet]. Dapat diunduh dari: http://repository.ipb.ac.id/ handle/123456789/279citation \&hl=en\&user $=\mathrm{dEn}-$ Ft9sAAAAJ\&citation_for_view $=$ dEnFt9sAAAAJ:u5HHmVD uO8C

2007. Sistem Penghidupan dan Nafkah Pedesaan: Pandangan Sosiologi Nafkah (Livelihood Sociology) Mazhab Barat dan Mazhab Bogor. [internet]. Jurnal Sodality. 01 (02): 1-24. Dapat diunduh dari: http://journal.ipb.ac.id/index.php/sodality/article/ view/5932

Ellis F. 1988. Peasant Economic: Farm Household and Agrarian Development. Cambridge [UK]: Cambrige University Press

Fisher JA, Patenaude G, Giri K, Lewis K, Meir P, Pinho P, ing the Relationship between Ecosystem Services and Poverty Alleviation: A Conceptual Framework. Ecosystem Services. Vol. 7: 34-45. DOI: 10.1016/j.ecoser.2013.08.002

Groom B, Palmer C. 2012. REDD+ and Rural Livelihoods. Biological Conservation. Vol. 154: 42-52. DOI: 10.1016/j.biocon.2012.03.002

Kollmuss A, Zink H, Polycarp C. 2008. Making Sense of the Voluntary Carbon Market: A Comparison of Carbon Offset Standards. [internet]. Dapat diunduh dari: http://www.globalcarbonproject.org/global/pdf/WWF_2008_A \%20comparison $\% 20$ of $\% 20 \mathrm{C} \% 20$ offset $\% 20$ Standards.pdf

Lyster R. 2011. REDD+, transparency, participation and resource rights: the role of law. Environmental Science \& Policy. Vol. 14: 118 - 126. DOI: 10.1016/j.envsci.2010.11.008

Juniarto B, Ngazis AN. 2013. Ini Penyebab Emisi Gas Rumah Kaca di Indonesia. [internet Dapat diunduh dari:http:// nasional.news.viva.co.id/news/read/452276-ini-penyebab-emisi-gas-rumah-kaca-di-indonesia

Newton P, Schaap B, Fournier M, Cornwall M, Rosenbach DW, DeBoer J, Whittermore J, Stock R, Yoders M, Brodnig G, Agrawal A. 2015. Community forest management and REDD+. Forest Policy and Economics. Vol. 56: 27-37. DOI: 10.1016/j.forpol.2015.03.008

Irawan S, Tacconi L, Ring I. 2013. Designing intergovernmental fiscal transfers for conservation: The case of REDD+ revenue distribution to local governments in Indonesia.Land Use Policy. Vol. 36: 47- 59. DOI:10.1016/j. landusepol.2013.07.001

Ituarte-Lima C, McDermott CL, Mulyani M. 2014. Assessing equity in national legal frameworks for REDD+: The case of Indonesia. [internet]. Environmental Science and Policy. Vol 44: 291 - 300. Dapat diunduh dari: http://dx.doi.org/10.1016/j.envsci.2014.04.003

Luttrell C, Resosudarmo IAP, Muharrom E, Brockhaus M, Syemour F. 2014. The political context of REDD+ in Indonesia: Constituencies for change. Environmental Science \& Policy. Vol. 35: 67-75. DOI: 10.1016/j.envsci.2012.10.001

Rosenberg A., Wilkinson J. 2013. Demonstrating approaches to REDD+ lesson from Kalimantan forest and climate partnership. [internet]. Dapat diunduh dari: http://climatepolicyinitiative.org/wp-content/uploads/2013/11/ SGG-Case-Study-Lessons-from-the-Kalimantan-Forests-and-Climate-Partnership.pdf

Skidmore S, Santos P, Leimona B. 2014. Targeting REDD+: An Empirical Analysis of Carbon Sequestration in Indonesia. World Development. Vol. 64: 781-790. DOI: 10.1016/j.worlddev.2014.07.013

Skutsch M, Vickers B, Georgiadou Y, McCall M. 2011. Alternative models for carbon payments to communities under REDD+: A comparison using the Polis model of actor inducements. Environmental Science \& Policy. Vol. 14: 140 - 151. DOI: 10.1016/j.envsci.2010.12.005

Sunderlin WD. 2010. Tenure: what will REDD mean for forest communities. [internet]. Dapat diunduh dari: http:// www.cifor.org/library/3055/tenure-what-will-reddmean-for-forest-communities/

Stone S, Leon MC, Frederics P. 2010. Perubahan Iklim \& Peran Hutan. [internet]. Dapat diunduh dari: http:// www.conservation.org/publications/documents/redd/ CI_Climate_Change_and the_Role_of_Forests_Bahasa_Manual_Komunitas.pdf

Strassburg B, Turner RK, Fisher B, Schaeffer R, Lovett A. 
2009. Reducing emissions from deforestation-The "combined incentives" mechanism and empirical simulations. Global Environmental Change. Vol. 19: 256 - 278. DOI: 10.1016/j.gloenvcha.2008.11.004

Suiseeya KRM, Caplow S. 2013. In pursuit of procedural justice: Lessons from an analysis of 56 forest carbon project designs. Global Environmental Change. Vol. 23: 968 - 979. DOI: 10.1016/j.gloenvcha.2013.07.013

Vatn A, Vedeld PO. 2012. National governance structures for REDD+. Global Environmental Change. Vol. 23: 422-
432. DOI: 10.1016/j.gloenvcha.2012.11.005

Wibowo A. 2010. REDD+ \& Forest Governance. Jakarta [ID]: Pusat Penelitian dan Pengembangan Perubahan Iklim dan Kebijakan, Badan Penelitian dan Pengembangan Kehutanan, Kementerian Kehutanan

Willemen L, Drakou EG, Dunbar MB, Mayaux P, Egoh BN. 2013. Safeguarding Ecosystem Services and Livelihoods: Understanding the Impact of Conservation Strategies on Benefit Flows to Society. Ecosystem Services. Vol. 4: 95-103. DOI: 10.1016/j.ecoser.2013.02.004 